\title{
Sliding Wear Study on the Valve-Seat Insert Contact
}

\author{
Edgar E. Vera-Cardenas ${ }^{1 *}$, Roger Lewis ${ }^{2}$, Tom Slatter ${ }^{2}$ \\ ${ }^{1}$ Department of Automotive Mechanical Engineering, Polytechnic University of Pachuca, Hidalgo, Mexico \\ ${ }^{2}$ Department of Mechanical Engineering, University of Sheffield, Sheffield, UK \\ Email: *eeverac@yahoo.com
}

How to cite this paper: Vera-Cardenas, E.E., Lewis, R. and Slatter, T. (2017) Sliding Wear Study on the Valve-Seat Insert Contact. Open Journal of Applied Sciences, 7, 42-49.

https://doi.org/10.4236/ojapps.2017.72004

Received: December 27, 2016

Accepted: February 13, 2017

Published: February 16, 2017

Copyright (c) 2017 by authors and Scientific Research Publishing Inc. This work is licensed under the Creative Commons Attribution International License (CC BY 4.0).

http://creativecommons.org/licenses/by/4.0/

Open Access

\begin{abstract}
The aim of this work was to investigate the sliding wear coefficient $k$, using an experimental sliding wear study on the valve-seat insert contact. Commercial inlet valve and seat inserts were used as test specimens. The tests were performed at room temperature and at $200^{\circ} \mathrm{C}$, using test duration of 72,000 cycles and 18,000 cycles, respectively, and both in dry sliding conditions. A load of 5 $\mathrm{N}$, an average speed of $22 \mathrm{~mm} / \mathrm{s}$ and sliding distance of $2.2 \mathrm{~mm}$ were used for all tests. The sliding wear coefficients were calculated using experimental and analytical methods. The wear volume was higher in the tests at $200^{\circ} \mathrm{C}$ both in valve and seat insert specimens. The principal wear mechanisms observed in valve specimen were oxidation and abrasion.
\end{abstract}

\section{Keywords}

Sliding Wear Coefficient, Valve-Seat Insert, Wear Mechanisms

\section{Introduction}

Some studies have been carried out in order to understand the wear mechanisms that occur in the valve/seat insert interface, some of them concentrating mainly on the inlet valves [1] [2] [3] and others focusing on exhaust valves [4] [5] [6] [7]. Some works have investigated the effects of the combustion pressure [8], the valve velocity [9], the fuel type [10], the cycle number [11], the high temperature [12] [13], the wear in valves of heavy duty engines [14] [15] and the effect of applying different hardening processes on the valve/seat insert interface [16] [17] [18] [19]. The operation temperature of inlet valves is between $180^{\circ} \mathrm{C}$ and $360^{\circ} \mathrm{C}$ [12]. For this specific work, a temperature of $200^{\circ} \mathrm{C}$ was used in order to realize an experimental study of sliding wear at the valve/seat insert interface. Some experiments also were performed at room temperature in order to have a compar- 
ison parameter of the wear volume. The objective of this study was to investigate the sliding wear coefficient $k$, at room temperature and $200^{\circ} \mathrm{C}$, using experimental methods.

\section{Experimental Details}

\subsection{Test Apparatus}

The experimental tests were carried out in dry conditions using a PLINT TE77 High Frequency Friction/Wear Machine. The specimens were placed as shown in the simplified schematic diagram (Figure 1). The moving specimen (seat insert) is mechanically oscillated against the fixed specimen (valve). A force transducer measures the friction force in both sliding directions.

\subsection{Test Specimen}

The specimens used are shown in Figure 2. They were obtained from a commercial valve and seat insert and prepared for placement in the PLINT machine. Their mechanical properties are shown in Table 1.

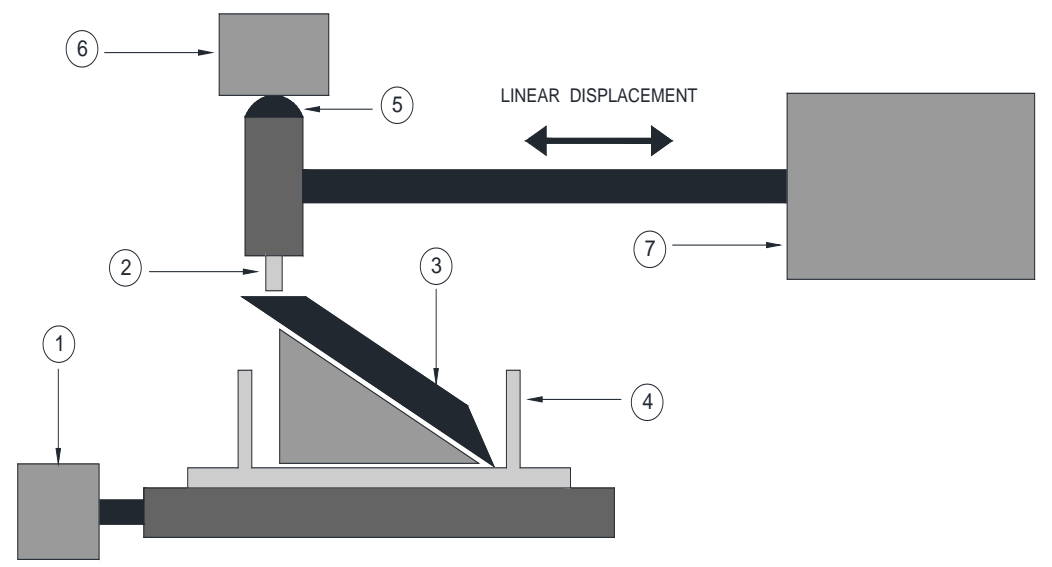

Figure 1. Simplified schematic diagram of High Frequency Friction Machine (1: Friction force transducer; 2: S.I. specimen; 3: Valve specimen; 4: Heater block; 5: Roller; 6: Normal load; 7: Oscillator driver).

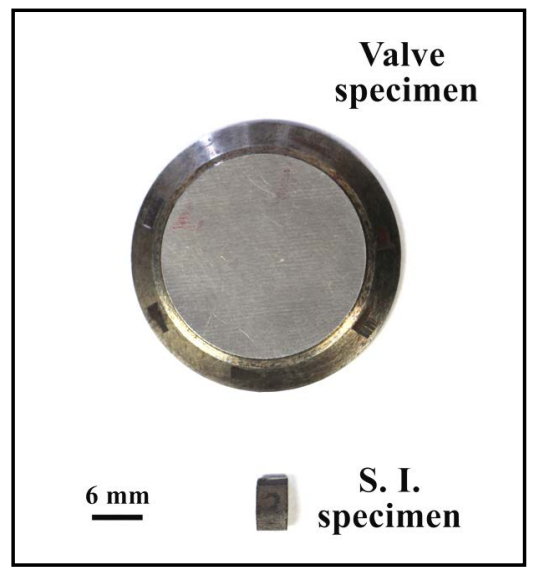

Figure 2. Test specimens. 


\subsection{Test Procedure}

Before all of the tests, the valve and seat insert specimens were cleaned of any residue oxide layer by washing in ethanol using an ultrasonic bath.

To know the effects of temperature in the $\mathrm{k}$ value, two types of tests were performed, one at room temperature (R.T.) and another at $200^{\circ} \mathrm{C}$. The valve and seat insert were placed in the rig as shown in the simplified schematic diagram (Figure 1). The load was selected in such a way that wear would be produced with a low number of cycles.

The tests performed at R.T. were run to 72,000 cycles and tests carried out at $200^{\circ} \mathrm{C}$ were run to 18,000 cycles. This was predetermined with several preliminary tests, to know how many cycles were necessary to cause damage on the surfaces. Table 2 shows the operating conditions of the tests conducted.

\section{Experimental Results and Discussion}

\subsection{Friction Behavior}

The coefficient of friction $(\mathrm{CoF})$ was measured in all tests. Friction coefficient increased during the early part of experiment, reaching an average value of 0.6 at the end of the test. Some debris was observed originating an increase in the friction coefficient.

\subsection{Wear Volume}

During a wear process, one of the major factors causing change in surface profiles is the material removal [20]. The determination of the wear volume in tribological testing is a key element [21], as it is more discriminative than the wear scar width/diameter. In this work, the total lost material was calculated by adding the wear volume from the valve and seat insert.

The width, length and depth of the valve specimen wear scars, were obtained using profilometry (Figure 3 ) and optical microscopy. Figure 3(a) and Figure 3 (b) show the profile of the wear scar for the tests at R.T. and at $200^{\circ} \mathrm{C}$, respectively. The average data of the depth, width and length of scars, as well as the

Table 1. Properties of the specimens.

\begin{tabular}{cccccc}
\hline Material & $\begin{array}{c}\text { Young's } \\
\text { modulus, GPa }\end{array}$ & $\begin{array}{c}\text { Poisson's } \\
\text { ratio }\end{array}$ & $\begin{array}{c}\text { Average } \\
\text { Hardness, HV }\end{array}$ & $\begin{array}{c}\text { Average } \\
\text { Roughness, Ra } \mu \mathrm{m}\end{array}$ \\
\hline Valve & $\begin{array}{c}\text { Martensitic, } \\
\text { low alloy steel }\end{array}$ & 210 & 0.29 & 564.8 & 0.409 \\
Insert & Cast seat insert & 120 & 0.26 & 470.2 & 1.963 \\
\hline
\end{tabular}

Table 2. Test parameters.

\begin{tabular}{cccccc}
\hline Test type & Valve temp., ${ }^{\circ} \mathrm{C}$ & Normal load, N & Stroke, mm & Frequency, Hz & Cycles \\
\hline A & 20 (R.T.) & 5 & 2.2 & 5 & 72,000 \\
B & 200 & 5 & 2.2 & 5 & 18,000 \\
\hline
\end{tabular}


wear volume, are shown in Table 3. As can be seen tests at $200^{\circ} \mathrm{C}$ produced higher wear volumes due to thermal softening causing the increased damage of the valve surface.

The length of the seat insert face (SIF) (Figure 4(a)) and seat insert upper face (SIUF) (Figure 4(b)) were measured before the tests (see Figure 5 for definitions). The wear volume in the seat insert specimens was calculated measuring the lost volume. It was verified in all tests, by optical microscopy, that the removed volume had a triangular section, represented schematically in Figure 5. The dimensions $\mathrm{a}, \mathrm{b}$ and $\mathrm{c}$, for each test specimen, were measured using optical microscopy, with which, the wear volumes were calculated (see Table 4).

\subsection{Optical Microscopy}

Figure 6 shows the images of the wear scars produced on the valve seating face

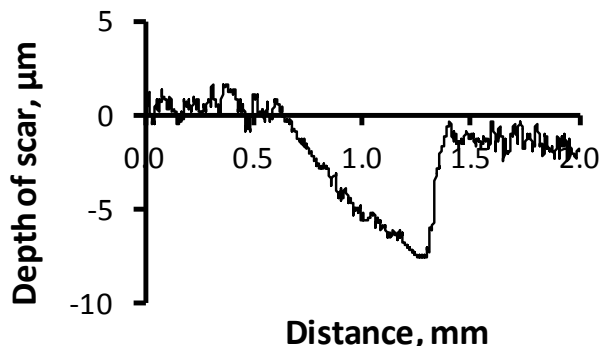

(a)

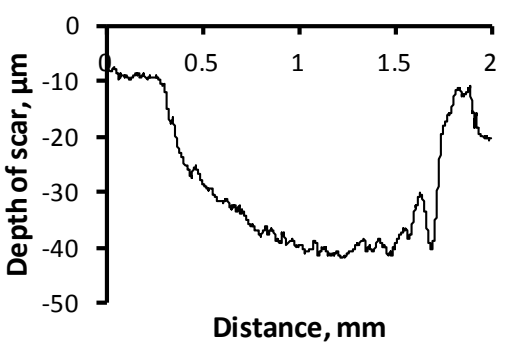

(b)

Figure 3. Profilometry of the valve wear scars: (a) R.T. test; (b) $200^{\circ} \mathrm{C}$ test.

Table 3. Average valve wear volume in valve tests.

\begin{tabular}{ccccc}
\hline Test & $\begin{array}{c}\text { Average depth, } \\
\mu \mathrm{m}\end{array}$ & $\begin{array}{c}\text { Average width, } \\
\mathrm{mm}\end{array}$ & $\begin{array}{c}\text { Average length, } \\
\mathrm{mm}\end{array}$ & $\begin{array}{c}\text { Average wear } \\
\text { volume, } \mathrm{m}^{3}\end{array}$ \\
\hline $\mathrm{A} 1$ (R.T.) & 7.14 & 0.85 & 3.25 & $1.97 \mathrm{E}-11$ \\
$\mathrm{~A} 2$ (R.T.) & 14.05 & 0.97 & 3.78 & $5.15 \mathrm{E}-11$ \\
$\mathrm{~A} 3($ R.T. $)$ & 17.39 & 0.89 & 3.44 & $5.32 \mathrm{E}-11$ \\
$\mathrm{~B} 1\left(200^{\circ} \mathrm{C}\right)$ & 27.79 & 1.39 & 3.67 & $1.42 \mathrm{E}-10$ \\
$\mathrm{~B} 2\left(200^{\circ} \mathrm{C}\right)$ & 55.45 & 1.79 & 3.59 & $3.56 \mathrm{E}-10$ \\
B3 $\left(200^{\circ} \mathrm{C}\right)$ & 23.5 & 1.75 & 3.56 & $1.46 \mathrm{E}-10$ \\
\hline
\end{tabular}
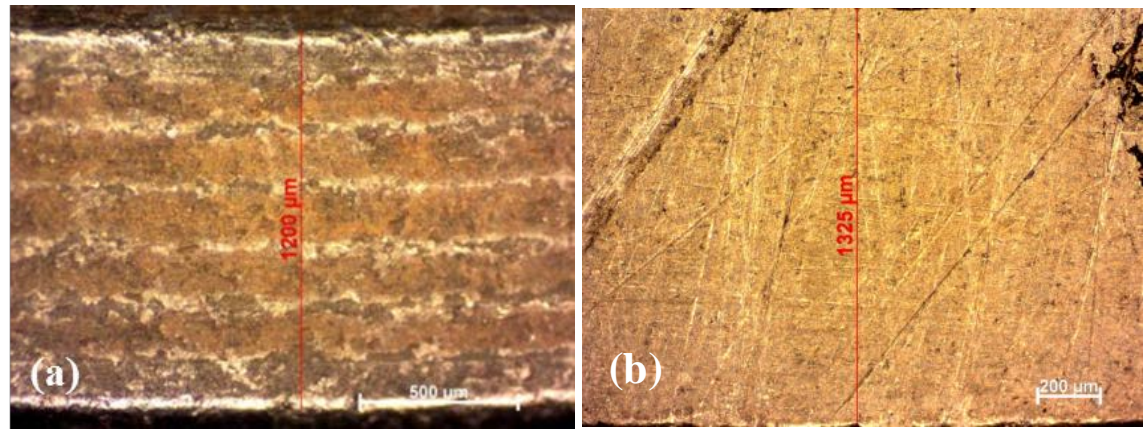

Figure 4. Dimensions before the test: (a) seat insert face; (b) seat insert upper face. 


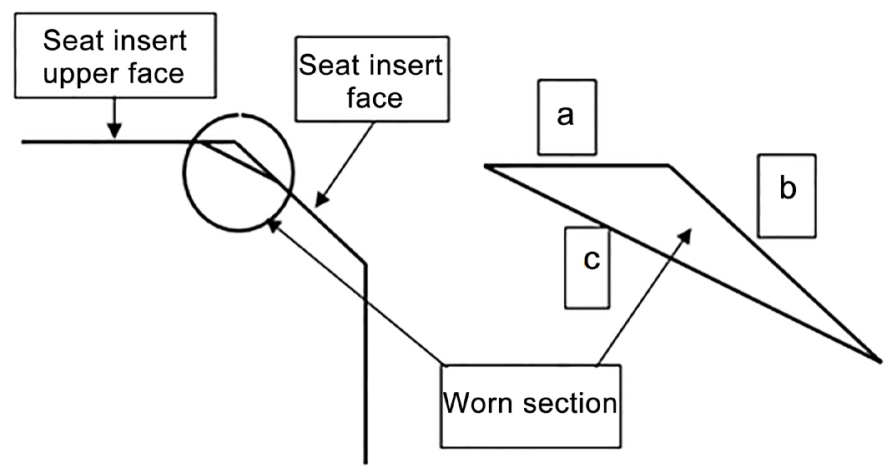

Figure 5. Lost volume on the worn surface.

Table 4. Average dimensions and wear volume for S.I. specimens.

\begin{tabular}{ccccc}
\hline Test & $\mathrm{a}, \mathrm{mm}$ & $\mathrm{b}, \mathrm{mm}$ & $\mathrm{c}, \mathrm{mm}$ & Volume, $^{3}$ \\
\hline A1 (R.T.) & 0.03 & 0.17 & 0.21 & $1.22 \mathrm{E}-11$ \\
A2 (R.T.) & 0.15 & 0.42 & 0.53 & $6.16 \mathrm{E}-11$ \\
A3 (R.T.) & 0.22 & 0.15 & 0.28 & $5.98 \mathrm{E}-11$ \\
B1 (200 $\left.{ }^{\circ} \mathrm{C}\right)$ & 0.21 & 0.33 & 0.46 & $1.30 \mathrm{E}-10$ \\
B2 $\left(200^{\circ} \mathrm{C}\right)$ & 0.24 & 0.51 & 0.41 & $1.67 \mathrm{E}-10$ \\
B3 $\left(200^{\circ} \mathrm{C}\right)$ & 0.29 & 0.39 & 0.38 & $1.79 \mathrm{E}-10$ \\
\hline
\end{tabular}
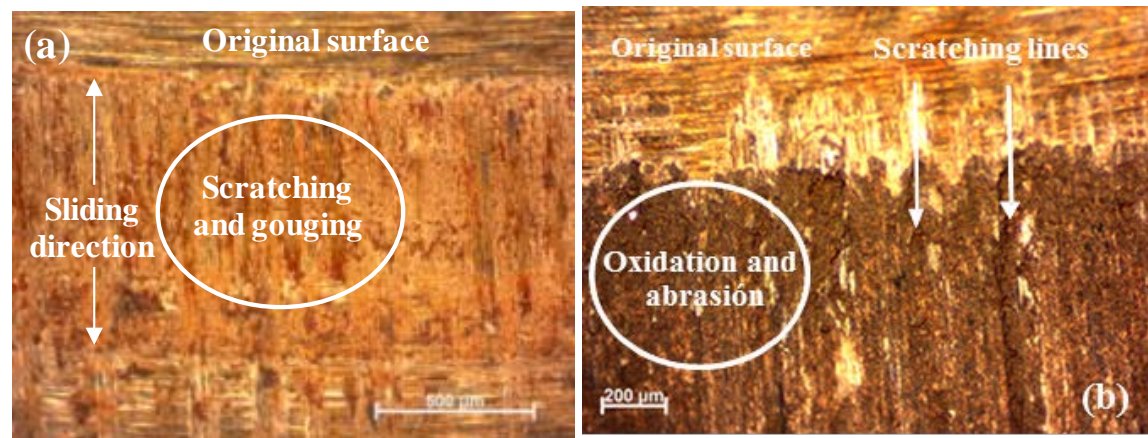

Figure 6. Optical microscopy of valve seating face after experiments: (a) R.T. test; (b) $200^{\circ} \mathrm{C}$ test.

when they were tested at R.T. and at $200^{\circ} \mathrm{C}$. For R.T. tests (Figure $6(\mathrm{a})$ ), the formation of scratching and gouging can be seen in the sliding direction. Debris at the edges of the wear scars was also observed. In the case of the tests at $200^{\circ} \mathrm{C}$ (Figure 6(b)), the main observation was oxidative and abrasive wear evidenced by scratching and gouging in the sliding direction.

Observations of the seat insert face (Figure 7(a) and Figure 7(b)) show the formation of surface cracking and pitting due to the frictional sliding, as well as the presence of scratching. It can also be seen that the size of the worn surface for R.T. tests were smaller than the tests at $200^{\circ} \mathrm{C}$.

\subsection{Sliding Wear Coefficient}

Previous studies have been carried out to generate the sliding wear coefficient $k$ 
[22]. In this work, $k$ was determined using the Archard's Equation [23] [24] (Equation (1)) and the results of the experimental tests.

$$
\boldsymbol{V}=\frac{\boldsymbol{k P} \delta N}{\boldsymbol{h}}
$$

where $V$ is the wear volume $\left(\mathrm{m}^{3}\right), k$ is the sliding wear coefficient, $P$ is the normal force at interface $(N), \delta$ is the slip at interface per cycle $(\mathrm{m}), N$ is the number of cycles and $h$ is the hardness $\left(\mathrm{N} / \mathrm{m}^{2}\right)$.

The final results for wear volumes and sliding wear coefficients are shown in Table 5. It can be seen in all tests that the $k$ value was higher in the tests at $200^{\circ} \mathrm{C}$, resulting in an average value of $1.17 \mathrm{E}-03$ and $5.01 \mathrm{E}-05$ for tests at R.T. The previous values of $k$ are compatible with the results reported by Rabinowicz [22] for fretting and abrasive wear in unlubricated conditions.

\section{Conclusions}

Valve specimens made of martensitic low alloy steel were put in frictional sliding tests against seat insert specimens made of cast tool steel.

1) The experimental procedure employed in this work, for the materials used, provides reliable results in wear volumes and sliding wear coefficients.

2) The wear volume was higher in the tests at $200^{\circ} \mathrm{C}$, both in valve specimens and seat insert specimens.
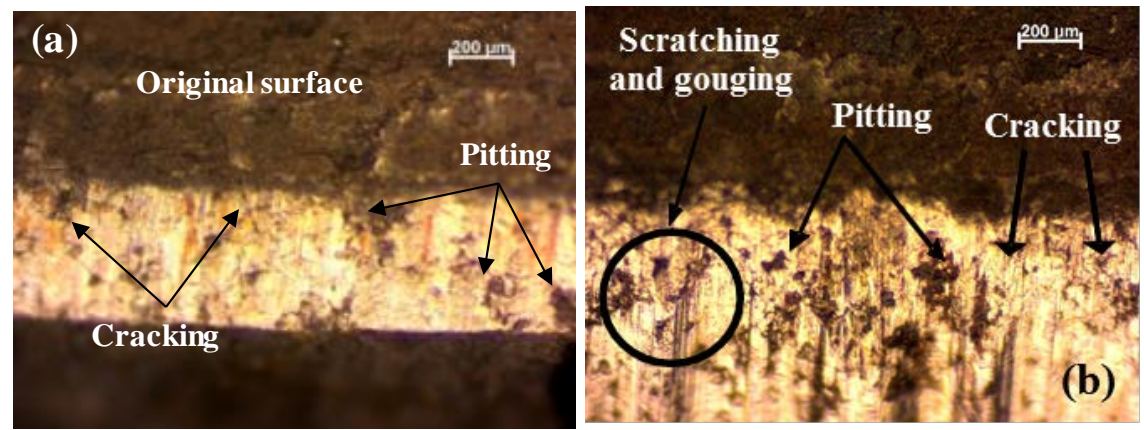

Figure 7. Optical microscopy on seat insert face after experiments, (a) R.T. test, (b) $200^{\circ} \mathrm{C}$ test.

Table 5. Summary of wear volumes and sliding wear coefficients.

\begin{tabular}{ccccccc}
\hline & \multicolumn{5}{c}{ R.T. } & \multicolumn{3}{c}{$200^{\circ} \mathrm{C}$} \\
\cline { 2 - 7 } Test & A1 & A2 & A3 & B1 & B2 & B3 \\
\cline { 2 - 7 } & $1.97 \mathrm{E}-11$ & $5.15 \mathrm{E}-11$ & $5.32 \mathrm{E}-11$ & $1.42 \mathrm{E}-10$ & $3.56 \mathrm{E}-10$ & $1.46 \mathrm{E}-10$ \\
$\begin{array}{c}\text { Valve wear } \\
\text { volume, } \mathrm{m}^{3}\end{array}$ & & & & & & \\
S.I. wear volume, $\mathrm{m}^{3}$ & $1.22 \mathrm{E}-11$ & $6.16 \mathrm{E}-11$ & $5.98 \mathrm{E}-11$ & $1.30 \mathrm{E}-10$ & $1.67 \mathrm{E}-10$ & $1.79 \mathrm{E}-10$ \\
Total wear volume, $\mathrm{m}^{3}$ & $3.19 \mathrm{E}-11$ & $11.31 \mathrm{E}-11$ & $11.30 \mathrm{E}-11$ & $2.72 \mathrm{E}-10$ & $5.23 \mathrm{E}-10$ & $3.25 \mathrm{E}-10$ \\
$k$ (Equation $(1))$ & $2.05 \mathrm{E}-05$ & $6.59 \mathrm{E}-05$ & $6.38 \mathrm{E}-04$ & $1.03 \mathrm{E}-03$ & $1.35 \mathrm{E}-03$ & $1.13 \mathrm{E}-03$ \\
Avg. $k$ & & $5.01 \mathrm{E}-05$ & & & $1.17 \mathrm{E}-03$ & \\
\hline
\end{tabular}


3) The principal wear mechanism observed in the wear scar surfaces of valve specimens was oxidation and abrasion.

4) The sliding contact produces several damages on the seat insert face, mainly characterized by cracking, pitting and scratching.

\section{Acknowledgements}

The work described in this paper was supported by CONACyT México and by the Tribology Group of The University of Sheffield, UK.

\section{References}

[1] Lewis, R., Dwyer-Joyce, R.S. and Josey, G. (2000) Trans. Mech. EngngIEAust, 24, 39-46.

[2] Wang, Y.S., Narasimhan, S., Larson, J.M. and Schaefer, S.K. (1998) Wear and Wear Mechanism Simulation of Heavy-Duty Engine Intake Valve and Seat Inserts. Journal of Materials Engineering and Performance, 7, 53-65. https://doi.org/10.1361/105994998770348043

[3] Zinner, K. (1963) Investigations Concerning Wear of Inlet-Valve Seats in Diesel Engines. Proc. ASME Oil Gas Power Conf., ASME Paper 63 OGP-1.

[4] Smoleńska, H. and Kończewicz, W. (2010) Failure Analysis of the Exhaust Valve Face in Diesel Marine Engine. Advances in Materials Science, 10, 11-18. https://doi.org/10.2478/v10077-010-0006-0

[5] Nurten, V. and Ahmet, E. (2010) GU Journal of Science, 23, 493-499.

[6] Forsberg, P., Hollman, P. and Jacobson, S. (2011) Wear Mechanism Study of Exhaust Valve System in Modern Heavy Duty Combustion Engines. Wear, 271, 2477 2484. https://doi.org/10.1016/j.wear.2010.11.039

[7] Nando, S.K. and Roskilly, A.P. (2003) Exhaust Valve Failure under Residual Fuel Operation. Journal of Marine Design and Operations, No. B2, 23-28.

[8] Von Berg, J., Ziermann, J., Reichert, R. and Obermeier, W. (1998) Measurement of the Cylinder Pressure in Combustion Engines with a Piezoresistive $\beta$ SiC-on-SOI Pressure Sensor. IEEE 4 th International Conference on High Temperature Electronics.

[9] Soo, J.H., Jin, K.C. and Han, Y.Y. (2006) A Study on Wear and Wear Mechanism of Exhaust Valve and Seat Insert Depending on Different Speeds Using a Simulator. Journal of Mechanical Science and Technology, 20, 2052-2060. https://doi.org/10.1007/BF02916322

[10] Soo, J.H., Soo, Y.K. and Jin, K.C. (2012) Study on Exhaust Valve and Seat Insert Wear Depending on Fuel Type. International Journal of Precision Engineering and Manufacturing, 13, 253-260. https://doi.org/10.1007/s12541-012-0031-5

[11] Chun, K.J., Kim, J.H. and Hong, J.S. (2007) A Study of Exhaust Valve and Seat Insert Wear Depending on Cycle Numbers. Wear, 263, 1147-1157.

https://doi.org/10.1016/j.wear.2007.02.006

[12] Ootani, T., Yahata, N., Fujiki, A. and Ehira, A. (1995) Impact Wear Characteristics of Engine Valve and Valve Seat Insert Materials at High Temperature (Impact Wear Tests of Austenitic Heat-Resistant Steel SUH36 against Fe-Base Sintered Alloy Using Plane Specimens). Wear, 188, 174-184.

https://doi.org/10.1016/0043-1648(95)06656-X

[13] Yang, L.C., Hamada, A. and Ohtsubo, K. (2000) Engine Valve Temperature Simula- 
tion System. SAE Technical Paper No. 2000-01-0564.

[14] Wang, Y.S., Narasimhan, S., Larson, J.M., Larson, J.E. and Barber, G.C. (1996) The Effect of Operating Conditions on Heavy Duty Engine Valve Seat Wear. Wear, 201, 15-25. https://doi.org/10.1016/S0043-1648(96)06945-1

[15] Comfort, A. (2003) An Introduction to Heavy-Duty Diesel Engine Frictional Losses and Lubricant Properties Affecting Fuel Economy-Part I. SAE Technical Paper No. 2003-01-3225. https://doi.org/10.4271/2003-01-3225

[16] Slatter, T., Taylor, H., Lewis, R. and King, P. (2009) The Influence of Laser Hardening on Wear in the Valve and Valve Seat Contact. Wear, 267, 797-806. https://doi.org/10.1016/j.wear.2009.01.040

[17] Kimihiko, A., Akira, M. and Akio, Y. (2005) Hardfaced Valve and P/M Valve Seat System for CNG and LPG Fuel Engines. SAE Technical Paper No. 2005-01-0718. https://doi.org/10.4271/2005-01-0718

[18] Shen, Q. and Shen, Y. (2000) Development of Laser Cladding Satellite F Alloy On Valve Face. World Automotive Congress, Seoul.

[19] Schlager, D., Theiler, C. and Kohn, H. (2002) Protection against High Temperature Corrosion with Laser Welded Claddings-Applied and Tested on Exhaust Valve Discs of Large Diesel Engines Burning Heavy Fuel Oil. Materials and Corrosion, 53, 103-110. https://doi.org/10.1002/1521-4176(200202)53:2<103::AID-MACO103>3.0.CO;2-R

[20] Pawlus, P. (1994) A Study on the Functional Properties of Honed Cylinders Surface during Running-In. Wear, 176, 247-254. https://doi.org/10.1016/0043-1648(94)90153-8

[21] ASTM Standard D7755-11 (2011) Standard Practice for Determination the Wear Volume on Standard Test Pieces Used by High-Frequency, Linear-Oscillation (SRV) Test Machine. ASTM International, West Conshohocken.

[22] Rabinowickz, E. (1981) The Wear Coefficient-Magnitude, Scatter, Uses. Journal of Lubrication Technology, 103, 188-194.

[23] Archard, J.F. (1953) Contact and Rubbing of Flat Surfaces. Journal of Applied Physics, 24, 981-988. https://doi.org/10.1063/1.1721448

[24] Archard, J.F. (1961) Single Contacts and Multiple Encounters. Journal of Applied Physics, 32, 1420-1425. https://doi.org/10.1063/1.1728372

\section{Scientific Research Publishing}

Submit or recommend next manuscript to SCIRP and we will provide best service for you:

Accepting pre-submission inquiries through Email, Facebook, LinkedIn, Twitter, etc. A wide selection of journals (inclusive of 9 subjects, more than 200 journals)

Providing 24-hour high-quality service

User-friendly online submission system

Fair and swift peer-review system

Efficient typesetting and proofreading procedure

Display of the result of downloads and visits, as well as the number of cited articles

Maximum dissemination of your research work

Submit your manuscript at: http://papersubmission.scirp.org/

Or contact ojapps@scirp.org 